\title{
Green Marketing and Purchase Behaviour of Generation Y-Consumers
}

\author{
Miss Michelle Kanonuhwa \\ University of Fort Hare. P. Bag X1314, Alice, 5700. South Africa \\ Email:michellekanonuhwa@gmail.com \\ Mr. T Chimucheka \\ University of Fort Hare. P. Bag X1314, Alice, 5700. South Africa \\ Email: tenchims@gmail.com
}

\section{Doi:10.5901/mjss.2014.v5n20p2785}

\begin{abstract}
This study discussed the impact of green marketing on the purchase behaviour of generation $Y$ consumers. By understanding green purchase behaviour of consumers, organisations can establish sustainable marketing strategies that appeal to different segments of the market. This is a desktop research. Information was gathered from various literature sources. The study recommends that a primary study be conducted to further investigate the relationship between these variables.
\end{abstract}

Keywords: green marketing, generation Y, purchasing behaviour

\section{Introduction}

American Marketing Association Seminar (AMA) held in 1975 first defined green marketing as studies regarding both adverse and/or positive impacts on the environment, energy consumption and the consumption of natural resources due to marketing (Cevreorman, 2010). According to Grant (2009), increasing awareness of environmental problems by the public and businesses has resulted in a shift in consumer lifestyles as they are adopting a more sustainable and environmentally friendly livelihood. In fact, some authors believe that environmental considerations should be integrated into all aspects of marketing, new product developments and communications (Ottman, 2011). The increase in environmentally friendly products is a result of environmental awareness and it resulted in the creation of new environmental ethics and consequently changes in consumption behaviour (Jang et al, 2011).

Businesses are adapting to this increased environmental concern by consumers through embarking on green marketing policies that appeal to the consumers. Sustainability is continuously becoming a major focus for businesses (Verdiem Corporation, 2008). Grant (2009) affirms this notion by stating that green marketing could be the next revolution. South Africa has made remarkable progress concerning environmental management by implementing strategies and laws to which businesses must adhere (Engel, 2008). Green marketing is a wide concept of marketing that is applicable to consumer goods, industrial goods and services (Erbaslar 2010).

\section{Statement of the Problem}

Papadopoulos et al (2010) are of the opinion that green consumers have become a driving force behind business strategies and that these ecological customers are creating a new economy around the globe. The rise in concern for the environment has seen consumers claiming to participate in efforts to sustain the environment (The Hartman Group, 2007), and to reflect these concerns in their purchasing tendencies. While this may hold some truth, some authors confer that there is a distinct gap between consumer claims and actual behaviour (McGuire, 1989; Chan and Lau, 2001; Park. et. al, 1994). Furthermore, the trending opinion that consumers are willing to pay more for green products (Laroche et. al, 2001), stems from the notion that environmentally friendly products are more dear to produce (Mahenc, 2008). Interestingly, (Ottman, 2011) refutes this by stating that consumers are unlikely to compromise on the traditional product attributes like price and quality. While Grant (2009) explains that green marketing could be the next revolution, Smith (2008) calls it a marketing ploy. Ottman (2011) divulged that the surge of green marketing has brought with it a wave of 
confusion and a lack of trust. Makower (2010) adds that consumers are unconvinced about green marketing claims by businesses. Due to these contrasting ideologies pertaining to green marketing, the conundrum therefore stands, is green marketing an economically viable marketing strategy and does it in any way affect the purchasing behaviour of the target market?

\section{Objective of the Study}

The objective of this study is to discuss the impact of green marketing on the purchase behaviour of generation $Y$ consumers in South Africa.

\section{Significance of the Study}

This study explores the impact of green marketing on the purchasing behaviour of generation $Y$ consumers in South Africa. Generation Y consumers represent the future of our society (Hume 2010). By understanding their green purchase behaviour, organisations can establish sustainable marketing strategies that appeal to this particular segment. Businesses are of the conception that adapting greener strategies costs money (Van der Zee, 2008) and they need to understand the impact this has on their largest consumer segment (generation $Y$ ) to avoid taking unnecessary risk. Consumers' reactions to a firm's marketing strategy have a great impact on the firm's success. Research findings will assist businesses to understand the green purchasing behaviour of generation $Y$ consumers and therefore develop an appropriate strategy and practical marketing outline to ensure success. The study also extends existing literature by focusing on the generation Y consumer segment in South Africa, a newly industrialised country (National statistics of the BRICS Group, 2013). This will be useful for future researches conducted on the subject at hand.

\section{Literature Review}

Green marketing, generation $Y$ consumers, purchase behaviour and theoretical models (reasoned action model and theory of planned behaviour) will be discussed in sections that follow.

\subsection{Green marketing}

Green marketing came into existence in 1980. Erbaslar (2010) defines it as a wide concept of marketing, which is applicable to consumer goods, industrialised goods and even to services. The AMA defined green marketing as the marketing of products that are presumably environmentally friendly and safe. Green marketing was highly driven by concern for the environment, which then led to companies advertising their commitment to reduce their climate impacts and the effect, this had on their products and services (Mendleson and Polonsky, 1995). Ottman (2011) mentions that green marketing is now mainstream and altering the whole marketing scene as we know it. Previous studies have shown that customers are willing to pay more for green products (Coddington, 1995 and Phillips, 1999). Green marketing explores the trend toward using manufacturing and marketing techniques aimed at reducing harmful effects on the environment (Winski, 1991). Interestingly Papadopoulos (2010) uncovered that implementing green marketing is challenging but despite this fact, stakeholders are still willing to adopt it. Over the years green marketing has become a controversial subject as some authors believe it is failing and not really going anywhere (Makower, 2013) while Ottman (2011) argues that green marketing as a whole is not failing but rather it is the green marketers who are failing to implement it strategically. Companies have responded by adopting green initiatives in their strategies for example green products and services design (Chan et al, 2013), green supply chain management (Tseng et al, 2013) and innovation practices (Lin et al, 2013). Mohajan (2012) uncovers that the adoption of green marketing in the society may not be easy in the short run but in the end, surely it will be profitable. Businesses assume that incorporating sustainability into their operations would cost money (Van der zee, 2008). This assumption is justified by the existence of what has been termed 'green costs' which include but are not limited to conversion costs and lack of support where there can be a bias against companies that go green.

\subsection{Generation Y consumers}

They are also known as the Net generation or the millennial generation. In this study they are referred to as generation $Y$ for the purposes of consistency. Material consumption fascinates this particular generation and they place much value on 
money (Chau and Ngai, 2010). Generation Y consumers represent the future of our society thereby making them relevant to business organisations (Hume, 2010). According to Kotler and Armstrong (2008), this generation consists of people born between 1978 and 2000. However, it is imperative to note that dates often vary with different sources. The demographics of South Africa (2011) indicate that this particular age group is the largest population group. Ottman (2011) names the generation $Y$ consumers as the likely new leaders of the modern-day green movement. Hsu, Chang and Chen (2012) opine that the unique characteristics of consumers significantly affect their purchasing behaviour. "Generation Ys believe that global climate change is caused by human activities and they are almost twice as likely to buy more green products as those consumers who think climate change is occurring naturally." (Ottman, 2011:6).

\subsection{Purchasing behaviour}

Consumer behaviour involve the study of individuals, groups or organisations and the various procedures they adopt to select and dispose of products, services or experiences to meet their needs as well as the impact of these procedures on society. It is difficult to influence behaviour without first impacting attitudes and values. However, (McGuire, 1989) pointed out that claims and attitudes may not always translate into actual behaviour. Green products are viewed as an acceptable option that escalates intention relative to actual behaviour. Purchasing behaviour for the purpose of this study will pay close attention to the purchase intention and/or purchase decision.

\subsection{Theoretical Framework}

The Reasoned Action Model (Fishbein and Azjen, 1975) and the Theory of planned behaviour (Azjen, 1985) are the two theoretical constructs that can contribute to the comprehension of this study.

\subsubsection{Reasoned Action Model}

This is an antecedent to the theory of planned behaviour. According to the theory of reasoned action, the execution of a specific behaviour is determined by the intention to perform the behaviour (Azjen and Eishbein, 1980). It suggests that behavioural intention is a product of two factors, attitude towards behaviour and subjective norms.

\subsubsection{Theory of Planned behaviour}

Azjen (1985) as an improvement to the Reasoned Action Theory proposed this theory. It incorporates perceived behavioural control such that behavioural intentions are a result of attitude towards behaviour, subjective norms and behavioural control. This theory is widely used for environmental researches. Sustainable behaviours are generally viewed as positive behaviours thus promoting behavioural intention. However, perceived behavioural control can be hindered by obstructions like the conception that one's behaviour will not have any impact.

\section{Conclusion and Recommendations}

This paper discussed the impact of green marketing on the purchase behaviour of generation $Y$ consumers. The objective of this study will be fully achieved by conducting primary research. The researchers recommend that a primary study be conducted to investigate if green marketing can influence the purchase behaviour of generation $Y$ consumers, and also to determine the extent of this influence, that is whether positively or negatively. Although qualitative research techniques, if applied carefully can also reveal some important information on this subject, this can be done better through a quantitative research design through the application of relevant statistical methods to test well formulated hypotheses.

\section{References}

Azjen, I. and Eishbein, M. 1980. Understanding attitudes and predicting social behaviour. Engelwood cliffs, NJ: Prentice-Hall

Azjen, I. 1985. From intentions to actions: A theory of planned behaviour in action control: From cognition to behaviour. Edited by Kuhl, J. and Beckman, J. Heidelberg: Springer-Verlog.

Azjen, I. 1991. The theory of planned behaviour. Organisational behaviour and human decision processes, 50, 179-211

BRICS Joint Statistical Publication. 2013. [online] Available at http://www.statsa.gov.za/ Accessed 6 April 2014. 
Chan, H.K., Wang, X., White, G., and Yip, N. 2013. An extent fuzzy-AHP approach for the evaluation of green products design. IEEE Trans, Eng. Mang. 60(2), 327-339

Chau, V. and Ngai, L. 2010. The youth market for internet banking services; perceptions, attitudes and behaviour. J. Serv, Market. 24(1), $42-60$

Coddington, W. 1990. "its no fad: environmentalism is now a fact of corporate life", Marketing news, 15 October p7

Demographics of South Africa. 2011. [Online] Available: http://en.Wikipedia.org/wiki/Demographics-of-South-Africa/ Accessed 2014, March 21.

Engel, D. 2008. Three stages to a greener company. [online] Available: http://wwwharmoniousliving.co.za. Accessed 6 April 2014

Erbaslar, 2010. The Gazanfer year 3, "green marketing, economics, sociology and politics magazine (e-zine). [Online] Available at http://wwwparadoks.org,ISSN. 1305-7979-Issue: 1. Accessed 6 April 2014

Fishbein and Azjen. 1975. Belief, attitude, intention and behaviour: An introduction to theory and research. Boston: Addison-wesley.

Grant, J. 2009. The green marketing manifesto. John wiley and sons.

Hume, M. 2010. Compassion without action: Examining the young consumers' consumption and attitude to sustainable consumption. Journal of World Business 45: 385-394.

Hsu, C.L., Chang, K.C., and Chen, M.C. 2012. Flaw experience and internet shopping behaviour: investigating the moderating effect of consumer characteristics. Systems research and behavioural science, 29, 317-322

Jang, Y., Kim, N., and Bonn, M. 2011. Generation Y consumers' selection attributes and behavioural intentions concerning green restaurants. Int. J. Hosp. Manag. 30(4). 803-81

Kotler, Phillip and Gary Armstrong 2008, Principles of Marketing. USA. Prentice-Hall

Kotler, P., Armstrong, G., Swee Hoon Ang, Siew Meng Leong., Chin Tiong Tan and David Tse. 2005. Principles of Marketing: an Asian Perspective. Singapore. Pearson/ Prentice-Hall.

Laroche, M., Bergeron, J., and Barbaro-Forleo, G. 2001. Targeting consumers who are willing to pay more for environmentally friendly products. Journal of consumer marketing, 18(6): 503-520.

Mahenc, P. 2008. Signalling the environmental performance of polluting products to green consumers. International journal of industrial organisations, 26: 59-68.

Makower, J, 2013. Failure of green marketing. [online] Available:http://venitism.blogspot.com/2013/10/failure-of-green-marketing.html. [27 March 2014]

Mendleson, N., and M.J. Polonsky 1995. Using strategic alliances to develop credible green marketing. Journal of consumer marketing 12: $4-18$

Ottman, J.A (2011). The new rules of green marketing, strategies, tools and inspiration for sustainable branding, Greenleaf Publishers

Ottman, J. (2011). Green marketing blog [online]. Available:http://www.greenmarketing.com/blog/comments/green-marketing-not-deadjust-misdirected. [19 May 2011]

Papadopoulos, I. Karagouni, G. Trigkas, M. and Platogianni, E. (2010). Green Marketing- the case of Greece in certified and sustainable managed timber products. Euro Med Journal of business, 5(2)

Phillips. 1999. as cited by Aseem Prakash. 2002. Green Marketing, Public Policy and managerial Strategies. Bus. Strat. Env. 11, 285297

Tseng, M.I. Wang, R. Chiu, A.S.F. Geng, Y. Lin, Y.H. 2013b. Sustainable consumption and production for Asia: Sustainability through green design and practice. J. Clean. Prod. 40, 1-5

Winski, J. 1991. Green Marketing: Big prize, but no easy answers. Advertising Age, 62, Green Marketing special report, GR3

Van der Zee, B. 2008. Green business, 1st edition: London: Dorling, Kingsley. 